\title{
Salinity intrusion and convective mixing in the Atlantic Equatorial Undercurrent
}

\author{
MARIONA CLARET, ROCÍO RODRÍGUEZ and JOSEP L. PELEGRÍ \\ Departament d'Oceanografia Física, Institut de Ciències del Mar, CSIC, Passeig Marítim de la Barceloneta 37-49, \\ 08003 Barcelona, Spain. E-mail: pelegri@icm.csic.es
}

\begin{abstract}
SUMMARY: This study investigates the advection of positive-salinity anomalies by the Equatorial Undercurrent (EUC) and their potential importance in inducing vertical convective mixing. For this purpose we use hydrographic and velocity observations taken in April 2010 along the western Atlantic equatorial ocean ( 32 to $\left.43^{\circ} \mathrm{W}\right)$. The high-salinity EUC core is a few tens of metres thick and occupies the base of the surface mixed layer and the upper portion of the surface thermocline. It leads to high positive values of the vertical salinity gradient, which in many instances cause statically unstable conditions in otherwise well-stratified regions. The unstable regions result in vertical convection, hence favouring the occurrence of step-like features. We propose that this combination of horizontal advection and vertical-instability leads to a sequence of downward-convective events. As a result the EUC salinity is diffused down to a potential density of 26.43, or about $200 \mathrm{~m}$ deep. This mechanism is responsible for water-mass and salt downwelling in the equatorial Atlantic Ocean, with a potentially large influence on the tropical and subtropical cells.
\end{abstract}

Keywords: Equatorial Undercurrent, high-salinity core, horizontal advection, convective mixing, step-like features.

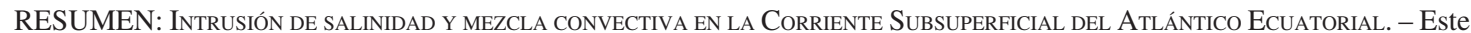
trabajo investiga cómo la advección de anomalías positivas de salinidad por la Corriente Subsuperficial Ecuatorial (CSE) puede inducir mezcla vertical convectiva. Con este fin se utilizan los datos hidrográficos y de velocidad recogidos en abril de 2010 en el margen occidental el océano Atlántico ecuatorial $\left(32 \mathrm{a} 43^{\circ} \mathrm{W}\right)$. El núcleo de alta salinidad tiene un espesor de varias decenas de metros, ocupando la base de la capa de mezcla y la parte superior de la termoclina superficial. Este núcleo, perteneciente a la CSE, explica la existencia de anomalías locales positivas de salinidad, que ocasionan que regiones muy bien estratificadas en algunos casos se vuelven estáticamente inestables. Esto induce convección vertical favoreciendo la generación de estructuras en escalones. Se propone que la combinación de los procesos de advección horizontal e inestabilidad vertical desencadena fenómenos de hundimiento convectivo. Como resultado la salinidad de la CSE es difundida hasta una densidad potencial de 26.43, localizada alrededor de los $200 \mathrm{~m}$ de profundidad. Este mecanismo es responsable del hundimiento de masas de agua y salinidad en el Océano Atlántico Ecuatorial, con la capacidad de influir en las células tropicales y subtropicales.

Palabras clave: Corriente Ecuatorial Subsuperficial, núcleo altamente salino, advección horizontal, mezcla convectiva, estructuras en escalones.

\section{THE ATLANTIC EQUATORIAL UNDERCURRENT}

Numerous pieces of evidence pointed early to the existence of an Atlantic Equatorial Undercurrent (EUC) (Neumann 1960, Metcalf et al. 1962, and references therein) but it was Metcalf et al. (1962), in a seminal paper, who first provided definitive evidence for its existence and described its major characteristics. These authors presented the cross-equatorial distribu- tions of temperature, salinity and oxygen, as well as current shear and geostrophic velocities (interpolated near the equator). A salty and high-oxygen EUC flows east along the equator, between $1^{\circ} \mathrm{S}$ and $1^{\circ} \mathrm{N}$ and from a few tens of metres to some $150 \mathrm{~m}$ depth, with maximum speeds at about $60 \mathrm{~m}$ in excess of $1 \mathrm{~m} \mathrm{~s}^{-1}$.

Metcalf and Stalcup (1967) showed that EUC waters have their origin in the southern hemisphere. The subtropical waters of the South Atlantic reach the equator via the North Brazil Current (NBC), sometimes 
after recirculating through the tropical South Atlantic (Stramma and Schott 1999), and retroflect just north of the equator to form the EUC (Flagg et al. 1986, Schott et al. 1998). The location and characteristics of this retroflection have substantial seasonal and interannual variability: sometimes it takes place less than $1^{\circ}$ north of the equator but sometimes it takes place as far as $7^{\circ} \mathrm{N}$; occasionally, the full NBC retroflects but in other instances there is substantial northward leakage either as the Guyana Current or as detached NBC rings (Hüttl-Kabus and Böning 2008, Silva et al. 2009).

Metcalf et al. (1962) first described the eastward penetration and spreading of the high-salinity EUC using field data from $10^{\circ} \mathrm{S}$ to $10^{\circ} \mathrm{N}$. They presented a transatlantic map of the maximum observed salinity between 25 and $200 \mathrm{~m}$ from $10^{\circ} \mathrm{S}$ to $10^{\circ} \mathrm{N}$. The salinity contours, made only with the maximum observed values in each zone, illustrate that waters with salinity greater than 37.0 enter the equatorial region through the NBC. Metcalf et al. (1962) also showed the alongequator eastward extension of high-salinity waters, which remain as high as 36.5 up to $15^{\circ} \mathrm{W}$ but rapidly decrease to less than 36.0 at $10^{\circ} \mathrm{W}$. These numbers were later confirmed by Gouriou and Reverdin (1992) across the Atlantic basin and by Schott et al. (1998) on the western margin.

The model of the tropical Atlantic of Philander and Pacanowsky (1986) finds a weak semi-annual oscillation signal for the EUC at $30^{\circ} \mathrm{W}$, with maximum values close to $1 \mathrm{~m} \mathrm{~s}^{-1}$ near $60 \mathrm{~m}$ depth in April and some 40 $\mathrm{m}$ deeper in November. These values are in qualitative agreement with cross-equatorial observations by Metcalf et al. (1962) and Gouriou and Reverdin (1992). Metcalf et al. (1962) show cross-equatorial sections at 18.5 and $13.5^{\circ} \mathrm{W}$ taken in April 1961 that display salinity maxima above 36.5 centred at the equator and $60 \mathrm{~m}$ depth. Gouriou and Reverdin (1992) present the temporal evolution of a cross-equatorial section at $4^{\circ} \mathrm{W}$ in 1983 and 1984, with a semi-annual signal characterized by velocity maxima in March followed by the intensification of the salinity signal in April (values exceeding 36.0).

Metcalf et al. (1962) also gave an early description of the existence of mixing at the EUC. Their data suggest that there is "a greater degree of mixing along the equator than is encountered to the north or south of it". They noted a core-salinity wedge thinning with eastward distance while the average salinity of the upper layer is nearly conserved. Metcalf et al. (1962) and Voorhis (1961) already emphasized the existence of intense vertical shear, associated with the EUC. Subsequently, the importance of shear-induced mixing at the EUC has been the subject of a number of equatorial mixing papers (e.g. Pacanowsky and Philander 1981, Peters et al. 1988, 1995, Hebert et al. 1991, Wang and Müller 2002, Jackson et al. 2008, Zaron and Moum 2009).

While shear-induced mixing is undoubtedly the main mixing mechanism in the Pacific, the Atlantic high-salinity EUC raises an alternative possibility. The salinity maximum in the Pacific EUC is influenced lo- cally, through meridional inflow from South Pacific tropical waters (Wyrtki and Kilonsky 1984). In contrast, the high-salinity Atlantic EUC core is of remote origin, so its eastward propagation may be viewed as an actual externally-forced intrusion. As a result, the mean ratio between vertical salinity and temperature differences is much larger in the Atlantic than in the Pacific. At the base of the EUC this ratio is $\delta S /$ $\delta T=0.5 / 10^{\circ} \mathrm{C}$ for the Pacific in a vertical distance of some $100 \mathrm{~m}$ versus $1.0 / 10^{\circ} \mathrm{C}$ for the Atlantic in a vertical distance of about $70 \mathrm{~m}$.

The $\delta S / \delta T$ Atlantic EUC mean vertical ratio, though large, is not sufficient to induce static instabilities leading to convective mixing. However, the concept of an anomalously salty intrusion propagating over relatively fresh waters raises the possibility of localized unstable conditions. The NBC salinity maximum, at depths of about 60 to $80 \mathrm{~m}$, is higher than 37.0 and the upper thermocline equatorial waters in the western Atlantic, at some $200 \mathrm{~m}$ depth, are nearly as low as 35.0 . This represents a salinity change of 2 units which would be able to overcome stable temperature differences as large as about $8^{\circ} \mathrm{C}$. The key factor is the degree of dilution experienced by the NBC water before it becomes the eastward flowing EUC, i.e. the swifter the recirculation the less disturbed the NBC will remain as it becomes the EUC, and the larger the equatorial vertical salinity gradient will be.

The main objective of this study is to investigate how sharp the EUC salinity core remains as it intrudes into the background equatorial temperature stratification and whether this may lead to situations of static instability. To the authors' knowledge this is the first study on equatorial convective mixing. To carry it out we use a novel data set, acquired along the western equatorial Atlantic in 2010. We will show that the process takes place from the American margin to as far as $32^{\circ} \mathrm{W}$ and results in the redistribution of salt from the core of the EUC to the subsurface equatorial layers. We do not know the final outcome of this salt transfer but, through the subtropical cells, it may be a source of salt to the tropical ocean.

We initially present the data set and then carry out several simple descriptions and analyses. First, we describe the eastward penetration of the EUC, paying special attention to the step-like vertical structures that appear immediately below its core. As the EUC travels east the vertical salinity gradient weakens and the stair-type structures become less ubiquitous. Next, we look for instances of static instability and examine their relation to the step-type structure. It turns out that there are unstable cases coincident with the sharp rises in the step-like structure, indicating well-stratified regions prone to experience convective events. Finally, we investigate the EUC water-mass and salt fluxes and conclude that convective mixing is responsible for distributing salt between the high-salinity EUC core down to a potential density anomaly of 26.45 . The paper ends up by briefly discussing what we believe are important 


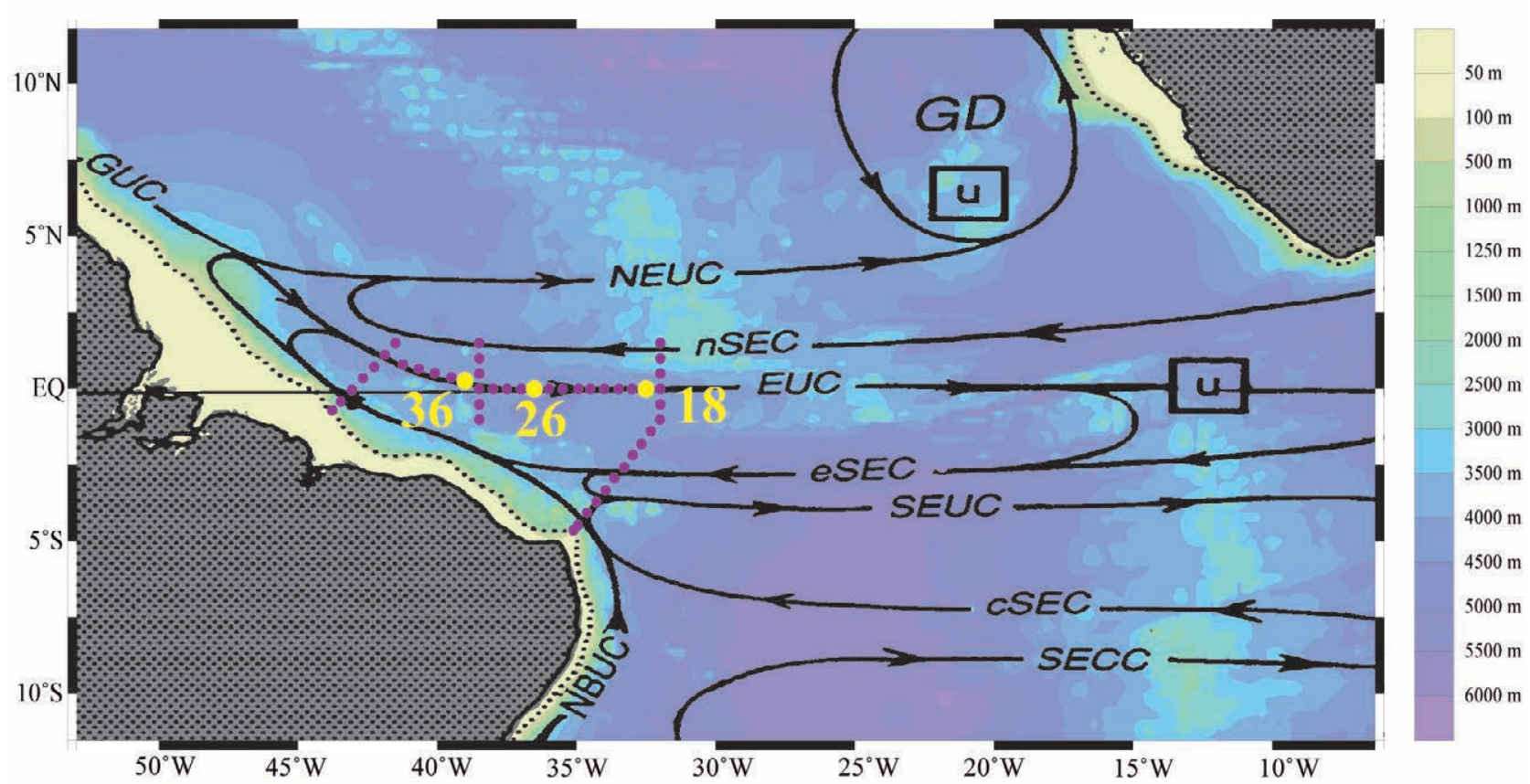

FIG. 1. - Map of the equatorial Atlantic with the 47 stations (coloured dots) forming part of the MOC2-Ecuatorial cruise. The three stations discussed in the text are drawn in yellow: from west to east, stations 36, 26 and 18 . A circulation scheme for the top $100 \mathrm{~m}$ of the water column during spring time, according to Stramma and Schott (1999), is shown. Acronyms account for the Guinea Dome (GD), the North Equatorial Undercurrent (NEUC), the Guiana Undercurrent (GUC), the South Equatorial Current (SEC) and Countercurrent (SECC), the Equatorial Undercurrent (EUC), and the North Brazil Undercurrent (NBUC). The SEC has northern (nSEC), equatorial (eSEC) and central (cSEC) branches. A colour version of this figure may be found in the online electronic manuscript.

implications of convective downwelling at the EUC core for the tropical and subtropical cells in the western tropical Atlantic.

\section{DATA SET}

The data set was collected between 7 and 18 April 2010, during the first part of MOC2-Ecuatorial cruise carried out with R/V Hespérides. A total of 47 conductivity-temperature-depth (CTD) casts, down to either $1500 \mathrm{~m}$ or the sea floor, were done in the equatorial region (Fig. 1). A SeaBird 911 Plus multi-parametric probe was employed, with duplicate salinity and temperature sensors to detect any possible drift. Salinity was further calibrated with the ship's auto-salinometer. Velocity data were acquired with the $75-\mathrm{kHz}$ vesselmounted Acoustic Doppler Current Profiler (ADCP). The ADCP had 8-m bins; the percentage of good-data points remained large until about $500 \mathrm{~m}$ depth, and decayed rapidly below that depth. The velocity values shown here correspond to the 1-hour average of the velocity data acquired immediately after the beginning of a CTD, while the ship was on station.

The data consist of one along-equator and three cross-equatorial sections, with $0.5^{\circ}$ spacing between stations (Fig. 1). The cruise was carried out while the ship was sailing westwards. The along-equatorial section contains 20 stations, running between $32^{\circ} \mathrm{W}$ and $41.5^{\circ} \mathrm{W}$. Between $32^{\circ} \mathrm{W}$ and $38.5^{\circ} \mathrm{W}$ the section followed west along the equator but then shifted NNW, attempting to follow the path of the EUC, as shown by the circulation scheme superposed onto Figure 1. This path was also suggested by the trajectory of a buoy dragged at $100 \mathrm{~m}$ that followed the EUC some three months before the cruise, as well as by the real-time salinity and velocity data gathered at the ship.

The western section was inclined some $45^{\circ}$ with respect to the equator, running between $\left(43.8^{\circ} \mathrm{W}\right.$, $\left.0.8^{\circ} \mathrm{S}\right)$ and $\left(41.5^{\circ} \mathrm{W}, 1.5^{\circ} \mathrm{N}\right)$, approximately normal to the hypothetical path for the retroflecting NBC. The central section runs along $32^{\circ} \mathrm{W}$ between $1.5^{\circ} \mathrm{N}$ and $1^{\circ} \mathrm{S}$. The eastern section runs along $38.5^{\circ} \mathrm{W}$ between $1.5^{\circ} \mathrm{N}$ and $1^{\circ} \mathrm{S}$ and then into the Brazilian shelf at about $\left(35.25^{\circ} \mathrm{W}, 4.8^{\circ} \mathrm{N}\right)$.

Three stations were used to characterize the western, central and eastern regions of our along-equatorial transect (Fig. 1). These reference locations are station $36\left(39^{\circ} \mathrm{W}, 0.25^{\circ} \mathrm{N}\right)$, station $26\left(36.5^{\circ} \mathrm{W}, 0^{\circ}\right)$, and station $18\left(32.5^{\circ} \mathrm{W}, 0^{\circ}\right)$. Notice that station 36 is quite distant from the western end of the along-equatorial section. This is because, despite our efforts, at the western end of the section we were not properly sampling the EUC. We will see later that the EUC retroflected south of $1.5^{\circ} \mathrm{N}$, entered our along-equatorial section at about station 38 , overshot the equatorial line south, and was reincorporated into our section near station 26 , thereafter following approximately east.

Additionally, we use trajectory data from a buoy launched at $\left(4^{\circ} \mathrm{S}, 32^{\circ} \mathrm{W}\right)$ on 12 December 2009 by the $\mathrm{R} / \mathrm{V}$ Hespérides on its way to the southern Atlantic. 


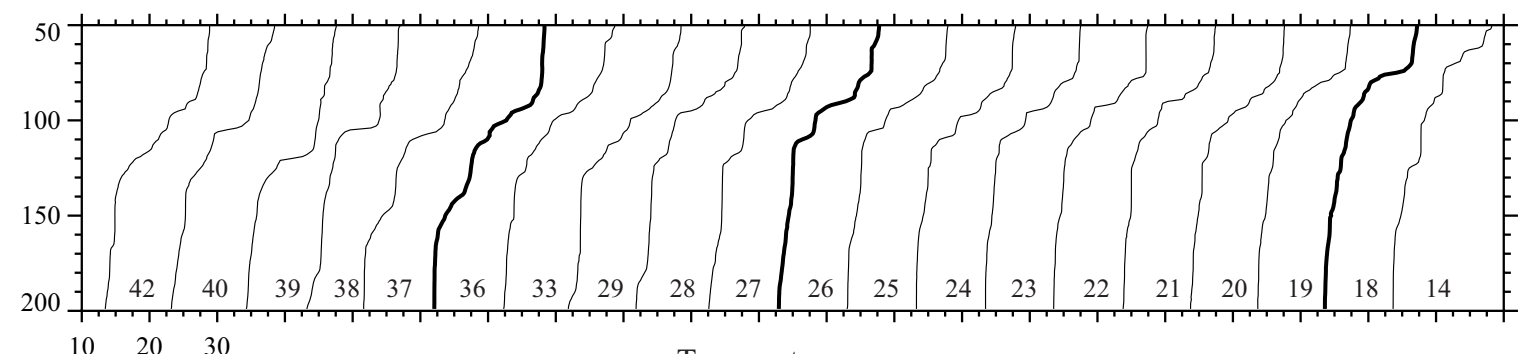

Temperature

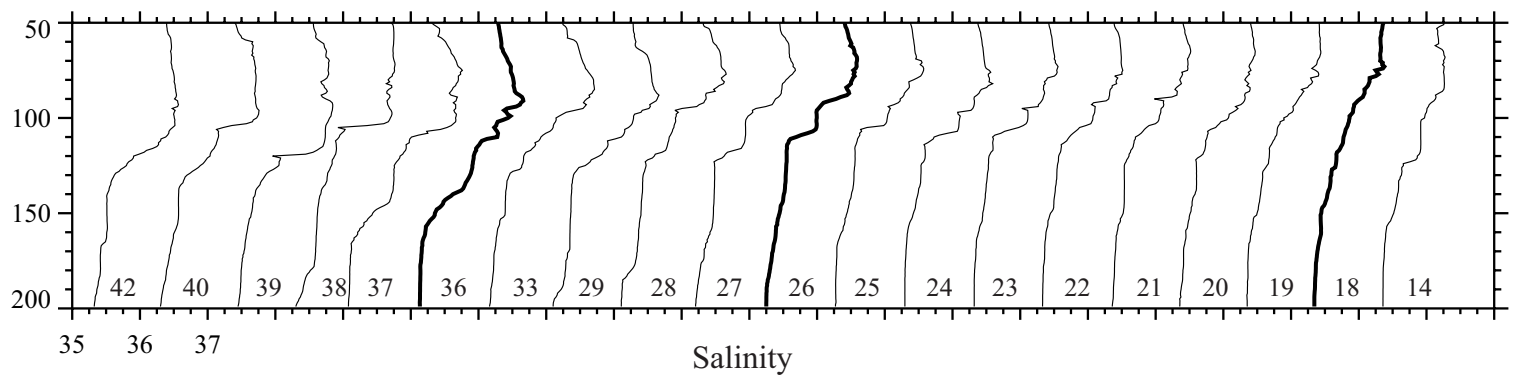

FIG. 2. - (Top) Temperature $T$ and (bottom) salinity $S$ profiles for the top $200 \mathrm{~m}$ of all stations along the equatorial section. For representation purposes, successive profiles have been displaced by $10^{\circ} \mathrm{C}$ for temperature and 1 unit for salinity.
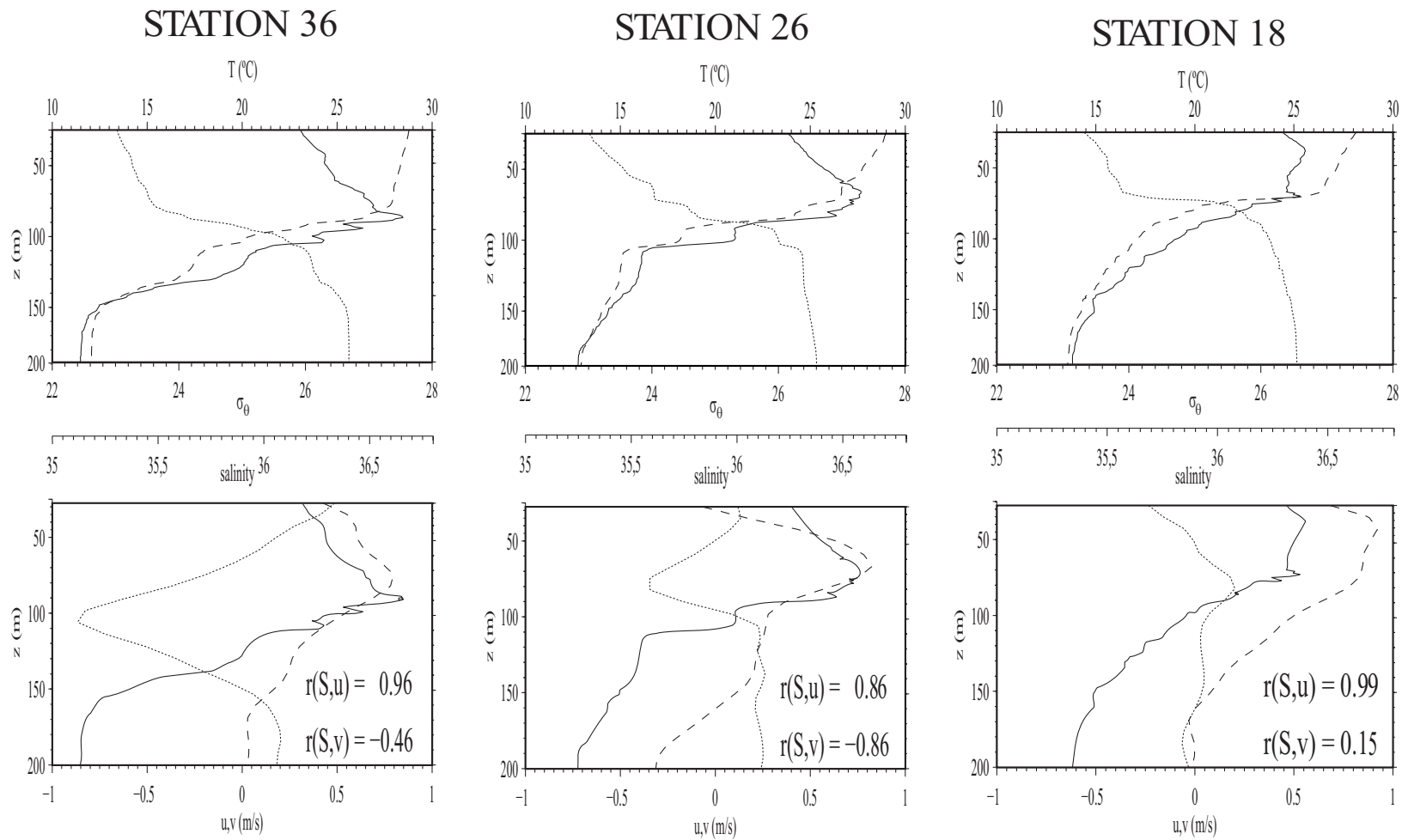

FIG. 3. - Depth profiles for the top $200 \mathrm{~m}$ of the water column at stations 36, 26 and 18: (upper panels) temperature $T$ (dashed line), salinity $S$ (solid line), and potential density anomaly $\sigma_{\theta}$ (dotted line); (lower panels) zonal velocity $u$ (dashed line), meridional velocity $v$ (dotted line), and salinity $S$ (solid line). The inset values are the normalized cross-correlation between the indicated variables.

This buoy was dragged with a $15-\mathrm{m}$ long and $0.7-\mathrm{m}$ diameter parachute at a nominal depth of $100 \mathrm{~m}$. It transmitted its position hourly via the Global Star satellite array. The buoy entered our area of study on about 15 January 2010 and left it two months later.

\section{ZONAL CHANGES IN THE SALINITY AND VELOCITY INTRUSION}

We observe that temperature and salinity structures change from west to east in the upper $200 \mathrm{~m}$ of the 
water column along the equatorial section (Figs. 2 and 3 ). Between the base of the surface mixed layer and the upper portion of the surface thermocline we find the EUC high-salinity core. The maximum salinity decreases and shallows, following this surface thermocline, when moving eastwards.

The surface mixed layer, as defined by near-constant surface temperatures, thins slightly from about $85 \mathrm{~m}$ at station 36 to about $70 \mathrm{~m}$ at station 18. Additionally, at station 18 the mixed layer displays relatively large vertical temperature gradients as compared with station 36. Consequently, since surface temperatures are nearly invariable, there exists a substantial decrease in the heat content of the mixed layer. Immediately below the surface mixed layer we find the surface thermocline, a region where the temperature decreases sharply from the surface values to relatively cold $12^{\circ} \mathrm{C}$ to $13^{\circ} \mathrm{C}$ waters. The thickness of the thermocline decreases east, approximately extending from 85 to $150 \mathrm{~m}$ at station 36 , from 80 to $110 \mathrm{~m}$ at the central station 26 , and from 70 to $95 \mathrm{~m}$ at the eastern station 18 (Fig. 2, top panel, and Fig. 3). In contrast, the thickness of the halocline behaves quite differently, remaining relatively constant at all stations (Fig. 2, bottom panel, and Fig. 3).

The zonal variations in the overall structure of the surface halocline and thermocline are accompanied by substantial changes in its fine structure, with large step-like features in the western and central stations (of the order of several tens of metres) changing to a much broken (just a few metres) structure at the eastern station (Fig. 2). These features are very clear in both the temperature and salinity fields but, because of their density-compensating character, are less appreciable in the density field (Fig. 3).

The step-like structures extend over most of the halocline, up to some $100 \mathrm{~m}$ below the salinity maximum (Fig. 2 and top panels of Fig. 3). These structures are most clear in those western and central stations along the path of the EUC (stations 37 and 36, and between stations 28 and 22). One single thick (30-40 m) step is found at the western stations 36 and 37 ; in the central region there are two much thinner steps (10-15 $\mathrm{m})$ which are clearly tracked between stations 23 and 28 , over some $2^{\circ}$ in longitude; at the eastern stations (stations 18 to 20 ) the vertical structure is much less clear, except at the easternmost position where three clear steps appear at different depths (station 14; see Fig. 2).

The vertical salinity profile keeps a close correlation with the vertical profiles of the zonal $u$ and meridional $v$ components of the horizontal velocity (bottom panels of Fig. 3). At the western stations, the flow is dominantly southwards with a subsurface velocity maximum which is found at the same depth as a relatively sharp subsurface salinity maximum. In contrast, at the eastern stations, the flow is nearly zonal and the salinity remains approximately constant in the whole surface layer structure, a finding that is coherent with an intense thick eastward velocity jet.
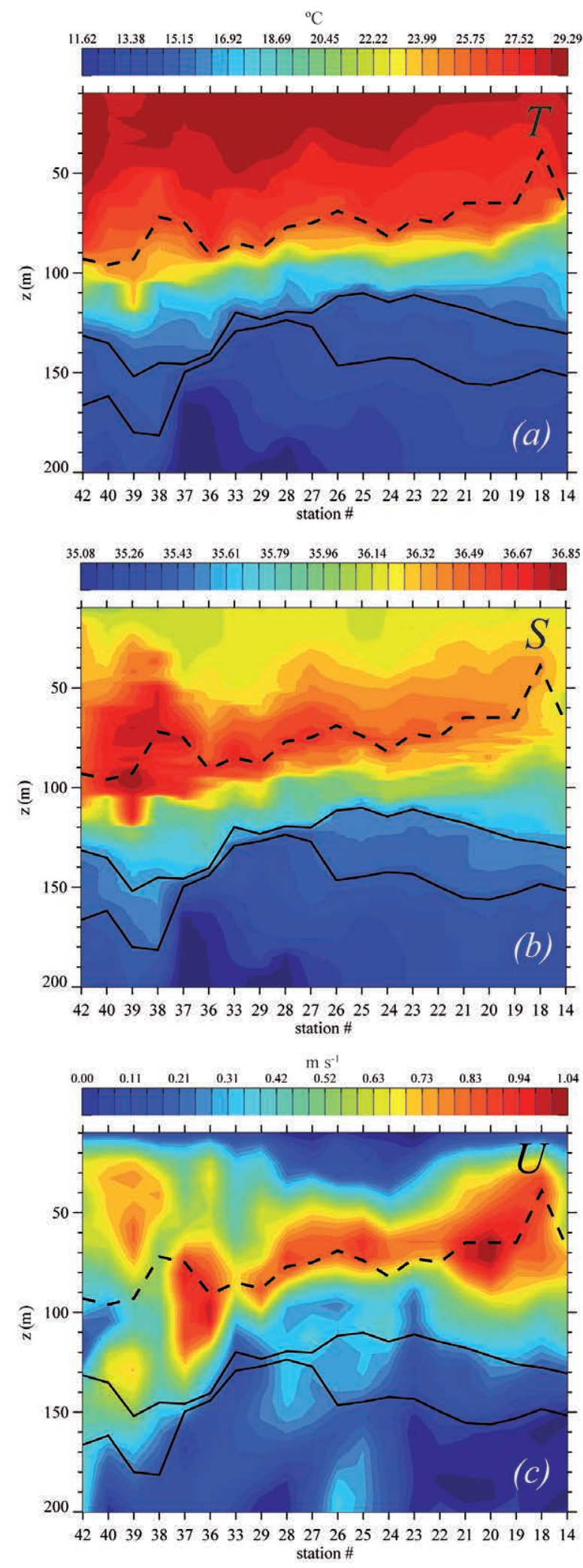

FIG. 4. - Vertical distribution of (a) temperature $T$, (b) salinity $S$, and (c) total speed $U=\left(u^{2}+v^{2}\right)^{1 / 2}$ along the equatorial section. The depths of the salinity maximum $z_{\max }=z\left(S=S_{\max }\right)$ (dashed line) and the isopycnals $\sigma_{\theta}=26.3$ and 26.43 (upper and lower solid lines, respectively) are indicated for reference. 
The eastward shallowing and sharpening of the thermocline is also shown in Figure 3. The salinity maximum is located immediately above the thermocline, at the base of the surface mixed layer, weakening from 36.9 at some western stations to 36.2 at the eastern end. The EUC core, defined here by salinity values above 36.4 , shallows and thickens towards the east and is not present any further east from station 19. The horizontal speed $\left(u^{2}+v^{2}\right)^{1 / 2}$ approximately follows the position of this salinity core, except near station 27 , where the salinity maximum thickens and the velocity has a local minimum. The velocity reaches its maximum values at the easternmost stations.

The transformation of the eastward-penetrating high-salinity EUC waters is illustrated in Figure 4. The EUC appears to vertically diffuse its salinity load in an asymmetrical way. The layers above the EUC core increase their mean salinity value gradually and the vertical gradient smoothes out, possibly as a result of turbulent diffusive processes. In contrast, under the EUC the halocline remains sharp except at the easternmost station 14 , which displays a markedly distinct character suggesting that the EUC has perhaps moved slightly away from the equator. In the layers below the EUC (east of station 28) the salinity increases intermittently with depth and distance, which may indicate that the downward salt transfer has taken place in discrete episodes, i.e. through successive mixing events, each extending no more than a few tens of metres.
As mentioned above, the subsurface high-salinity core is well correlated with the magnitude of the velocity field along the equatorial section, with the depth of maximum salinity and velocity values decreasing from about $85 \mathrm{~m}$ on the western margin to $70 \mathrm{~m}$ at the eastern stations. This correlation is also maintained in the horizontal distribution, at the level where the subsurface salinity is maximum $z_{\max }$ (Fig. 5). At the western stations we find a tongue of maximum salinity values $S\left(z=z_{\max }\right)=S_{\max }$ which stretches northeast across the equator and continues east centred at approximately $0^{\circ}$. This eastward salinity penetration is clearly related to the velocity field, suggesting that the EUC follows a retroflecting path along the equator. This correlation remains on the eastern margin, now with maximum velocity and salinity values found at all stations south of the equator.

The retroflection of the NBC as the EUC is confirmed by the trajectory of a buoy that entered the region on 15 January 2010, some three months previous to our measurements, and left it 60 days later, on 15 March 2010 (Fig. 5). The buoy was dragged at $100 \mathrm{~m}$ but the rope between the surface buoy and the drag was substantially tilted. Our estimate, extrapolated from instrumented buoys with similar characteristics, is that the drag was probably between 50 and $60 \mathrm{~m}$ depth, i.e. near the depth of maximum EUC velocities. Despite the time difference between the velocity measurements and the transit of the buoy, the good agreement between the velocity field and the buoy trajectory suggests that

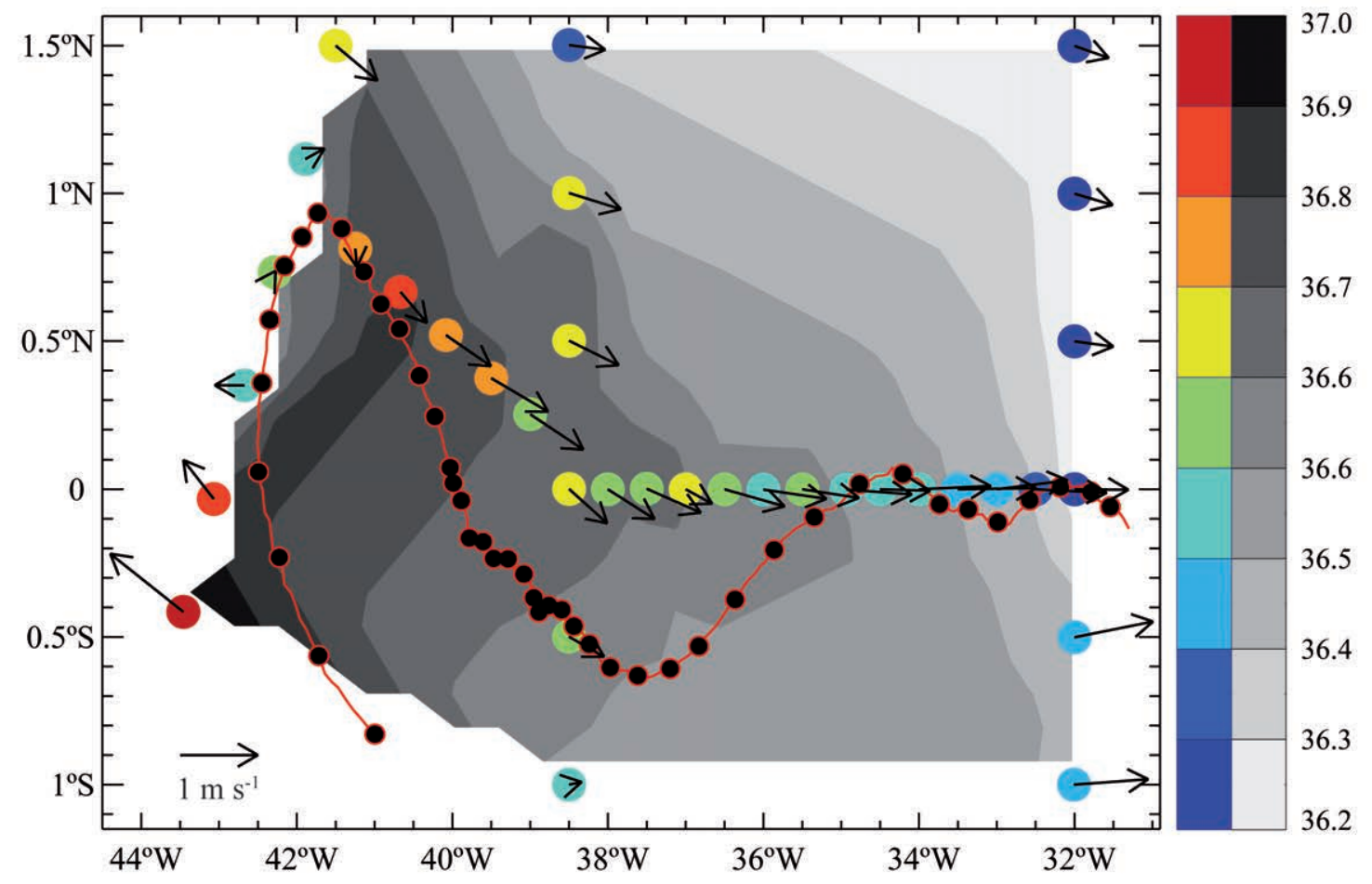

FIG. 5. - Horizontal distribution of the salinity maximum $S_{\max }$ together with the velocity vectors at the maximum salinity level, $z_{\max }=z\left(S=S_{\max }\right)$. The colour code represents the actual salinity values at the station, the grey code indicates the interpolated salinity field. On top of this map we have plotted the trajectory of a subsurface buoy that cruised through the region for 60 days. Tick marks along this trajectory illustrate the position every 32 hours, starting on 18 January 2010 in the southwest. 

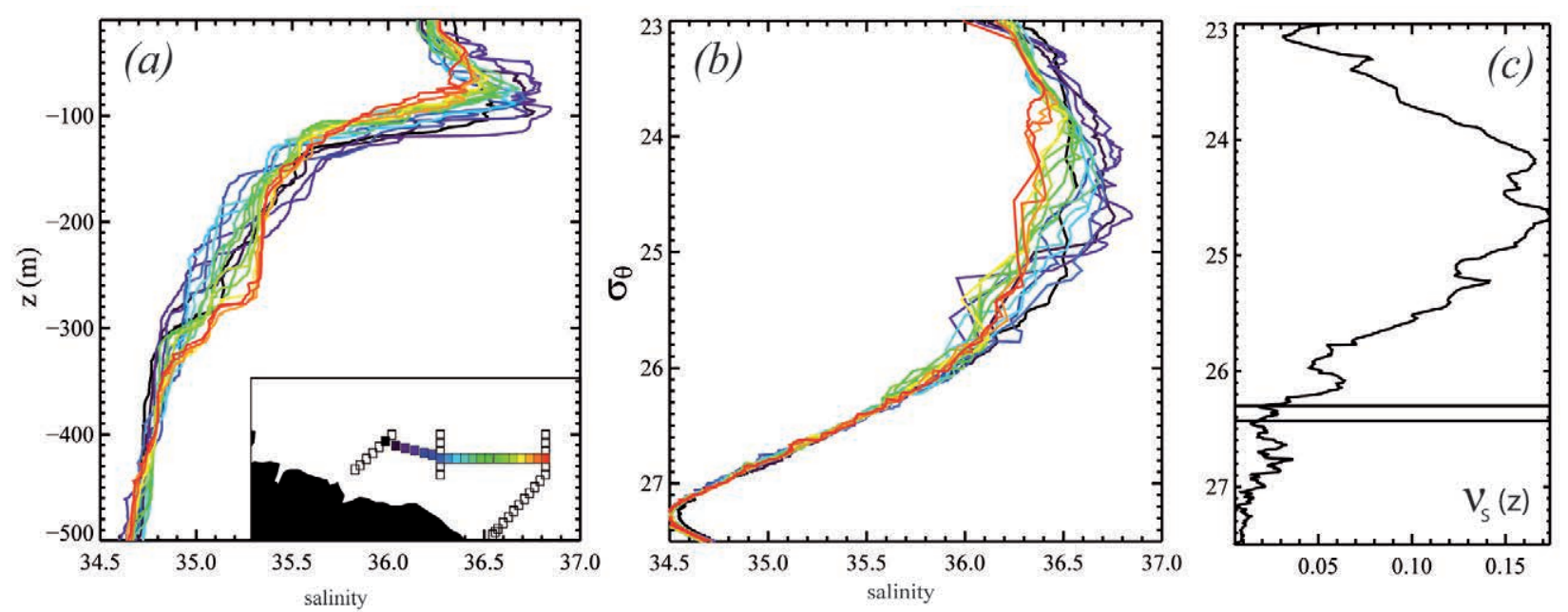

FIG. 6. - Vertical distribution of salinity $S$ as a function of (a) depth and (b) potential density for all stations along the equatorial section. The inset map in panel (a) shows the colour code for the position of each station. (c) Standard deviation of salinity $v_{S}$ as a function of potential density; the upper horizontal line denotes the potential density level $\left(\sigma_{\theta}=26.3\right)$ where $v_{S}$ is less than 0.2 of the maximum $v_{S}$ value, while the lower horizontal line denotes the potential density level $\left(\sigma_{\theta}=26.43\right)$ with minimum $v_{S}$ within the top $200 \mathrm{~m}$. A colour version of this figure may be found in the online electronic manuscript.

our equatorial section reasonably tracked the path of the EUC, except possibly for the westernmost stations.

We can use the equatorial section to examine the changing character of the EUC as it flows east (Fig. 6). The salinity-depth representation (Fig. 6a) nicely shows the eastward weakening and shallowing of the salinity core. It also shows the existence of a considerable change in the surface halocline with longitude: a relatively sharp halocline extending from 100 to over $300 \mathrm{~m}$ at the western stations and a less intense halocline barely reaching $170 \mathrm{~m}$ at the eastern ones. At the base of this surface halocline the salinity has much higher values at the eastern stations (35.35 at 250 $\mathrm{m})$ than at the western stations ( 34.75 at about $400 \mathrm{~m}$ ). A noteworthy consequence is the creation of a second halocline at the eastern stations, ranging between about 250 and $400 \mathrm{~m}$. This halocline represents the transition between the transformed EUC subsurface layers (between about 170 and $250 \mathrm{~m}$ ) and the underlying Antarctic Intermediate Waters (AAIW) (Stramma and Schott 1999, Stramma et al. 2005).

The salinity-density representation (Fig. 6b) confirms the eastward weakening of the salinity core but also shows how the density level of the salinity maximum does not change significantly with longitude, being located approximately near $\sigma_{\theta}=24.5$ at the western stations and $\sigma_{\theta}=24.0$ at the eastern stations. A comparison of Figures $6 \mathrm{a}$ and $6 \mathrm{~b}$ shows that, as we move eastwards along the equatorial section, the vertical position of the 24.5 density anomaly level deepens by nearly $100 \mathrm{~m}$. Further, we may appreciate that below some reference density level all curves merge together (Fig. 6b), indicating that the dispersion in Figure 6a is a result of the vertical displacements of the isopycnals in the zonal direction. To determine the reference density level, we calculated the standard deviation of salinity as a function of density anomaly. This devia- tion is maximum around the salinity core and reaches a minimum value at $\sigma_{\theta}=26.43$ (Fig. 6c). This isopycnal therefore coincides with single isohaline and isotherm surfaces, suggesting the eastward propagation of an unchanged water mass; with this perspective this isopycnal is taken as the reference level $\sigma_{r}$.

One principal feature of Figure 6a is the zonallychanging salinity stratification of the shallow sharp halocline, the one located immediately below the salinity maximum. The vertical gradient at the western stations, almost 2 salinity units in about $100 \mathrm{~m}$, is about twice the gradient at the eastern stations. In order to quantify this change in stratification we fitted the salinity profiles, using the least squares method, to an exponential function $S=S_{\max } \exp \left[a\left(z-z_{\max }\right)\right]$, where $a$ is a parameter indicative of the degree of (unstable) salinity stratification. Figure 7 shows this fit for the three reference stations and how the parameter changes with eastward distance. Except for the westernmost station, probably located outside the EUC path, this parameter decreases towards the east, suggesting that the western region may be more prone to undergo salt-induced convective instabilities. We next examine the possibility of such unstable salinity-driven processes.

\section{STATIC INSTABILITY}

In the upper layers of the equatorial Atlantic the stability of the water column is determined by the balance between temperature stability $\eta=\alpha \partial T / \partial z$ and salinity instability $\varsigma=\beta \partial S / \partial z$, where $\alpha=-(1 / \rho) \partial \rho / \partial T$ and $\beta=-(1 / \rho) \partial \rho / \partial S$ are the thermal and salinity expansion coefficients, respectively. Changes in density (at constant pressure) are the result of changes in salinity and temperature, as $d \rho=(\partial \rho / \partial T) d T+(\partial \rho / \partial S) d S$. Therefore, static instability occurs when $\partial \rho / \partial z=\alpha \rho(\partial T / \partial z)+$ $\beta \rho(\partial S / \partial z)=\rho(-\eta+\varsigma)>0$, or $\eta-\varsigma<0$. 


\section{STATION 36}

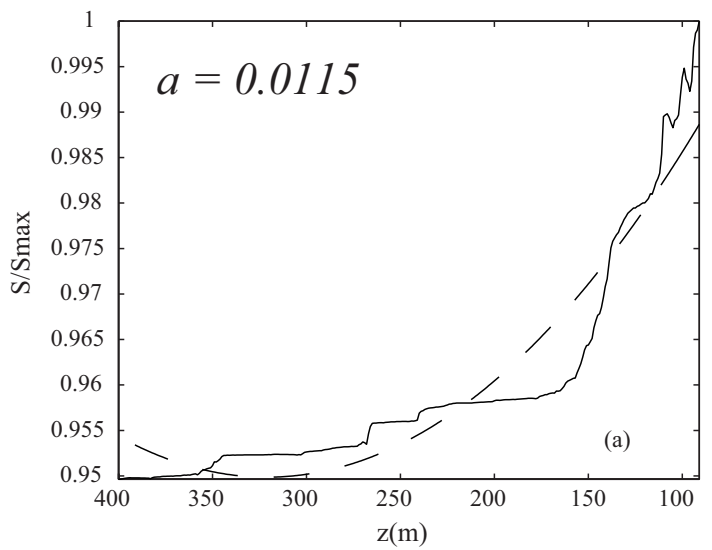

\section{STATION 18}

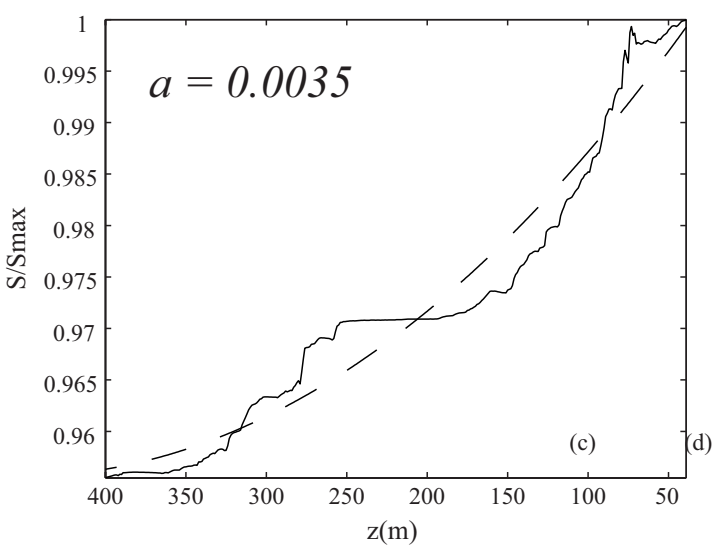

STATION 26
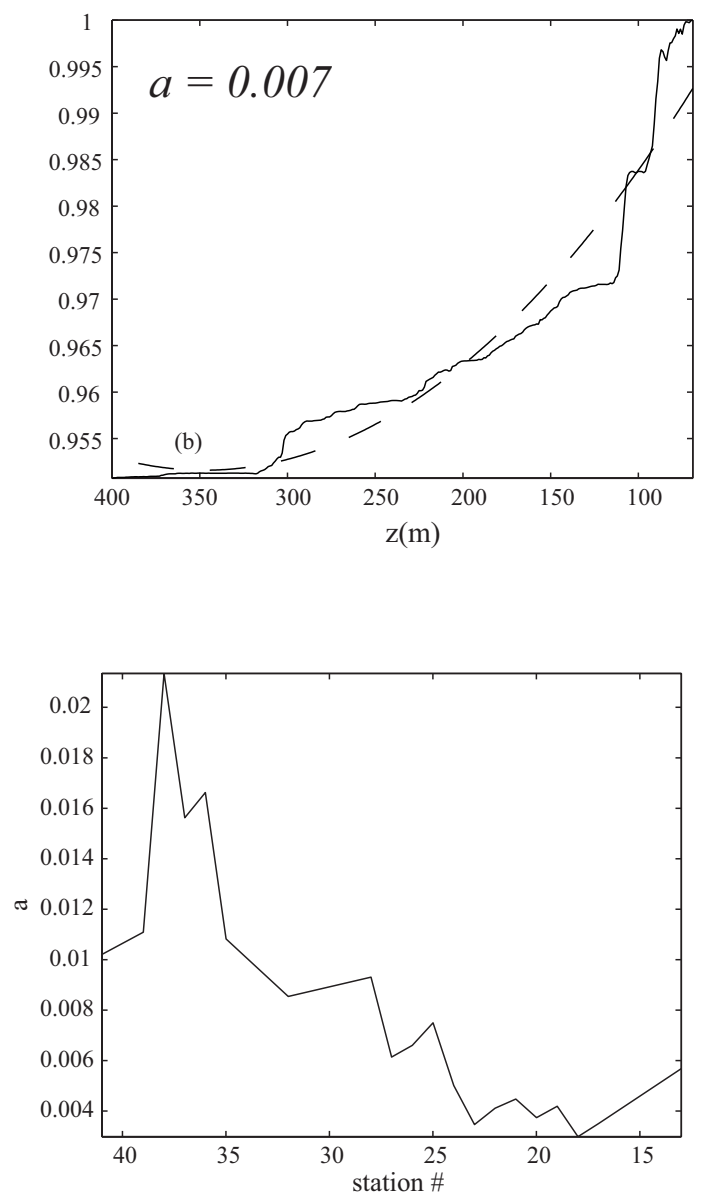

FIG. 7. - (a, b, c) Exponential functions (dashed lines) adjusted to the normalized salinity profiles $S / S_{\max }=\exp \left[a\left(z-z_{\max }\right)\right](\operatorname{solid}$ lines) at stations 36,26 and 18, respectively. The coefficient $a$ in the exponential adjustment is indicated. (d) Coefficient $a$ plotted as a function of station number along the equatorial section (from west to east).

The left panels in Figure 8 show the distribution of both $\eta$ and $\varsigma$ in the top $200 \mathrm{~m}$ of our three reference stations. On the one hand, the distribution of $\varsigma$ is controlled by the salinity maximum $S_{\max }$ level ( $\varsigma$ is negative above this level and positive below it) and by the intensity of the halocline (the vertical extension of the halocline does not change significantly but its intensity does). On the other hand, $\eta$ is always positive and its distribution is controlled by the extension of the (nearly) mixed surface layer (shallowing from some 85 to $70 \mathrm{~m}$ as we move east) and by the vertical extension of the thermocline (thinning drastically from about 70 to $20 \mathrm{~m}$ as we move east).

On the basis of these considerations we may separate the vertical domain into three different regions. First, the region above the salinity maximum is always stable $(\eta-\varsigma>0)$ as both temperature and salinity are stabilizing, i.e. $\eta>0$ and $\varsigma<0$. Immediately below we find the surface thermocline (which is shallower than the halocline), where both $\eta$ and $\varsigma$ are large; the thinner the thermocline, the more likely it is that the stabilizing temperature effect will dominate over the unstabilizing salinity field. Finally, we find the fraction of the surface halocline located below the surface thermocline; here the stabilizing temperature effect has decreased but the unstabilizing salinity field still remains.

In the right panels of Figure 8 we show the vertical distribution of $\eta-\varsigma$, which illustrates the existence of these three regions. The region with large positive $\eta-\varsigma$ values shallows and thins as we move east, essentially following the thermocline. The gross distribution of these positive $\eta-\varsigma$ values is dominated by the temperature stratification, the $\eta$ term, with several peaks as a result of the step-like thermal structure. In this same region, we find some instances where $\eta$ is large but the magnitude of the $\varsigma$ term is even larger (left panels of Fig. 8), resulting in negative $\eta-\varsigma$ values that could respond to vertically convective regions.

It could be possible, however, that the negative $\eta-\varsigma$ values were associated with the "treads" or well-mixed regions rather than with the "risers" or well-stratified regions in the step-like structure. Negative $\eta-\varsigma$ values within a tread are not a significant indicator of static instability as they may simply reflect some small inver- 


\section{S TATION 36}
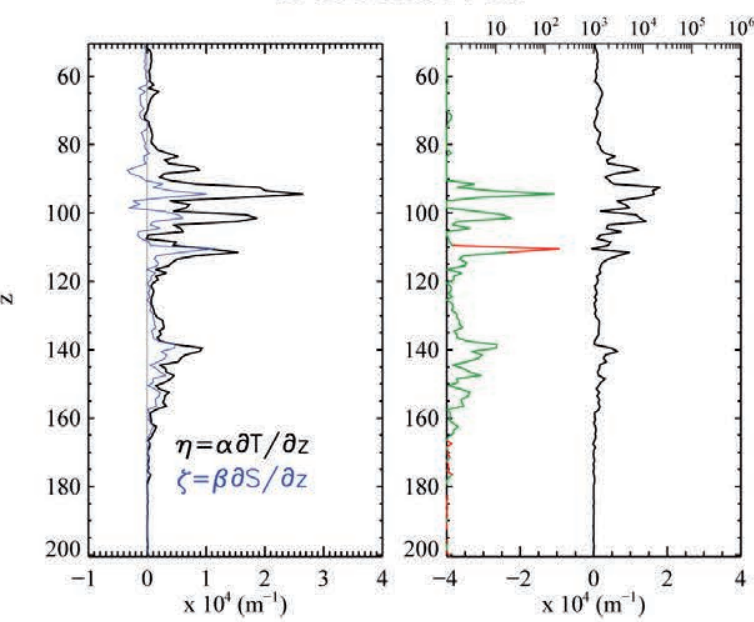

S TATION 26
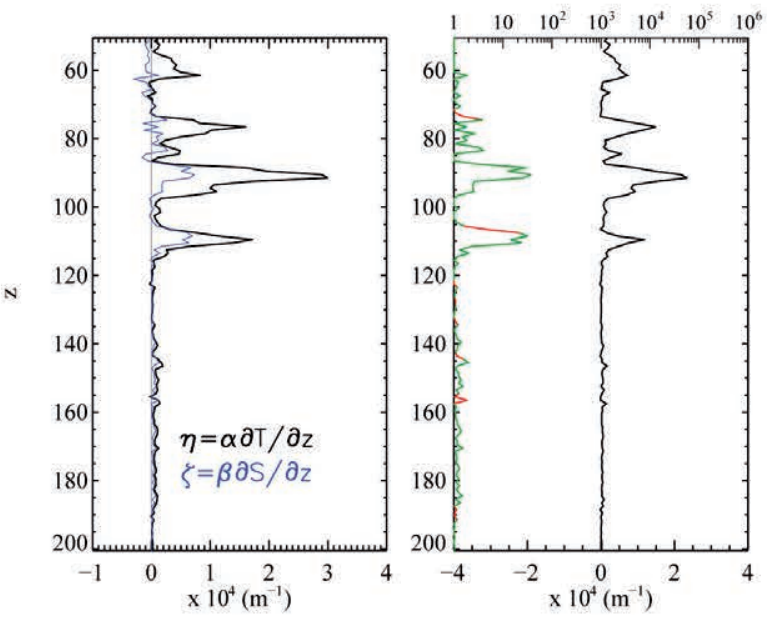

STATION 18
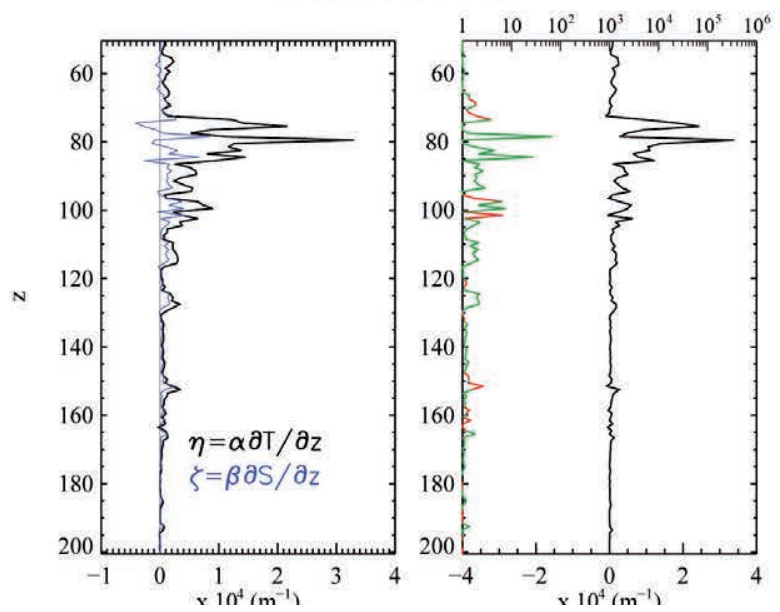

FIG. 8. - (Left panels) Vertical distribution of the temperature stability $\eta=\alpha \partial T / \partial z$, (black line) and salinity instability $\varsigma=\beta \partial S / \partial z$ (blue line) variables. (Right panels) Vertical distribution of $\eta-\varsigma$ (black line) and the instability variable $I$ (green and red lines respectively denote positive and negative values). Negative $I$ values correspond to vertically convective regions. sion within an already well-mixed region. On the other hand, if we find $\eta-\varsigma$ negative values in well-stratified regions, then the interpretation is that convective mixing is about to take place.

The treads have small $\eta$ and $\varsigma$; the sign of $\eta-\varsigma$ may be either positive or negative and its magnitude will also be small. The risers, on the other hand, have a large $\eta$ or $\varsigma$, or both; if the riser is statically stable then $\eta-\varsigma$ will be positive, if the riser is dominated by the unstabilizing effect of salinity ( $\varsigma$ positive) then $\eta-\varsigma$ will become negative. In order to differentiate between the two cases we formulated an instability parameter $I$ that decreases the amplitude of instabilities within treads but increases the amplitude of those within risers), namely

$$
I=\frac{\eta-\varsigma}{|\eta-\varsigma|} \exp [c(|\eta|+|\varsigma|-|\eta-\varsigma|)],
$$

where $c$ is a large number, here conveniently selected as $2.5 \times 10^{6}$. The fraction $(\eta-\varsigma) /|\eta-\varsigma|$ gives the sign of static stability while the exponential term (enhanced through the large $c$ factor) is used to decrease the amplitude of $I$ when both $\eta$ and $\varsigma$ are small (treads) and to increase it when either one is large (risers). Therefore, large negative $I$ values are indicative of vertically convective regions.

At the western and central stations, where the halocline extends as deep as the thermocline, we find instances where these large positive values are accompanied by neighbouring negative $\eta-\varsigma$ values, indicating instability (Fig. 8, right panels). At the eastern stations the halocline is less intense but extends much deeper than the thermocline, so instances of negative $\eta-\varsigma$ values are found below the thermocline within this moderately intense halocline. These results point to the zonal EUC as the cause for high horizontal advection of salinity that leads to vertical mixing when salinity destabilization overcomes the effect of temperature stratification.

\section{WATER-MASS AND SALT FLUXES}

We turn finally to examine the potential importance of convective vertical mixing in the redistribution of mass and salt by the EUC. The underlying idea is that this process may lead to a downward vertical flux of salt, away from the EUC core and into potentially divergent regions. To this end, we define the water $F$ and $F_{S}$ salt transport by the EUC (per unit width) as follows:

$$
\begin{gathered}
F\left(x, \sigma_{\theta}\right)=\int_{\sigma_{r}}^{\sigma_{\theta}}\left(u^{2}+v^{2}\right)^{1 / 2} \frac{\partial z}{\partial \sigma_{\theta}} \partial \sigma_{\theta}, \\
F_{S}\left(x, \sigma_{\sigma}\right)=\int_{\sigma_{r}}^{\sigma_{\theta}}\left(u^{2}+v^{2}\right)^{1 / 2} S \frac{\partial z}{\partial \sigma_{\theta}} \partial \sigma_{\theta} .
\end{gathered}
$$

The lower limit of the integral is taken as the reference level where no salinity anomalies are present, 

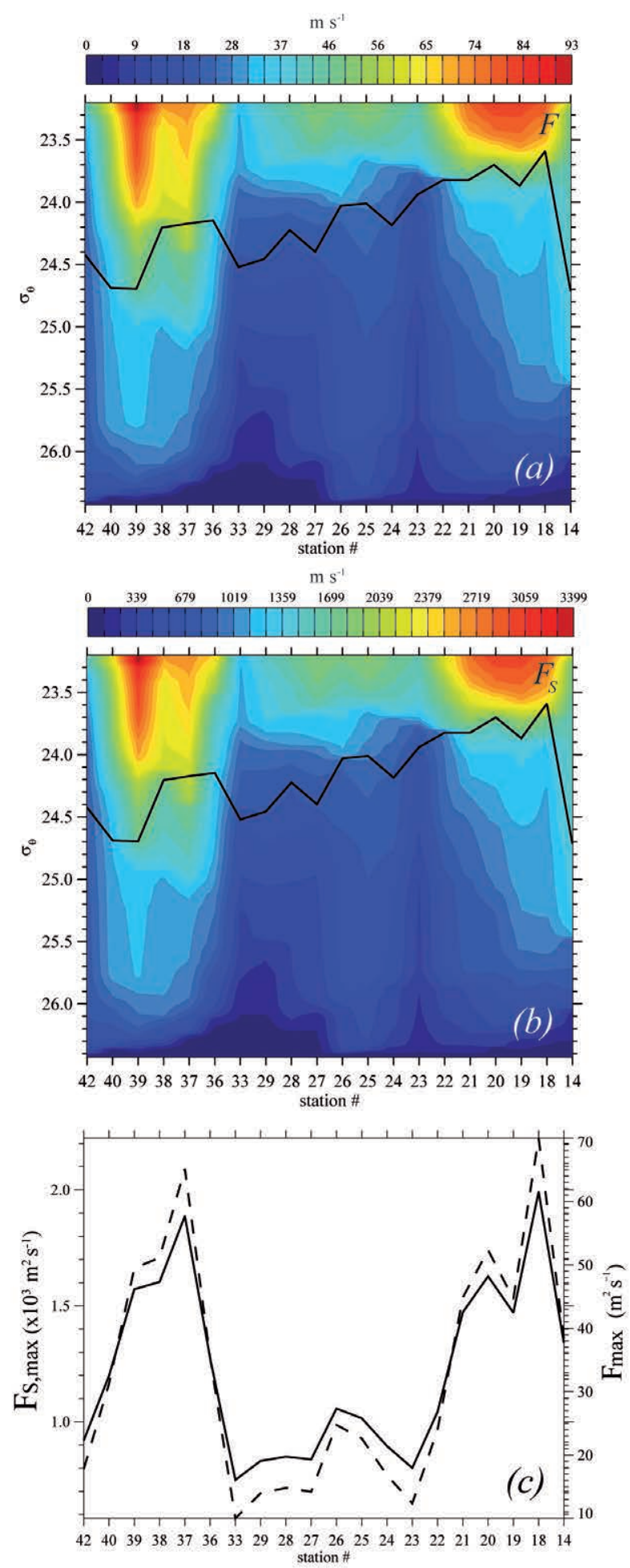

Fig. 9. - (a) Water-mass $F_{S}$ and (b) salt $F$ transports (per unit width), integrated from $\sigma_{\theta}=26.43$ until each potential density level, plotted as a function of station number along the equatorial section (from west to east). The solid black line indicates the location of the salinity maximum $S_{\max }$ level at each station. (c) Water-mass and salt transports in the potentially convective region, $F_{\max }$ and $F_{S \max }$, obtained by integrating from $\sigma_{\theta}=26.43$ until the salinity-maximum density level, $\sigma_{\max }=\sigma_{\theta}\left(S=S_{\max }\right)$. $\sigma_{r}=26.43$, assumed to respond to the absence of vertical convection (Fig. 6c). Each of these variables is a function of both the position along the EUC path (here denoted as $x$ ) and the upper density limit of the integral.

Figure 9a,b shows the distribution of both $F$ and $F_{S}$ as a function of station (here taken as a proxy for $x$ ) and density level for the upper limit of the integral. The two variables have very similar distributions as both salinity $S$ and total speed $\left(u^{2}+v^{2}\right)^{1 / 2}$ have subsurface maxima at a similar depth position (bottom panels of Fig. 3). The maximum change with density occurs near the location of the maximum velocity and salinity values, at density levels shallower than $\sigma_{\theta}=25.0$.

We may define the potentially convective-unstable region as the region that runs from $\sigma_{r}=26.43$ to the $\sigma_{\max }$ density level, the latter corresponding to the salinity maximum at each station, $S\left(\sigma_{\theta}=\sigma_{\max }\right)=S_{\max }$. The variables $F$ and $F_{S}$ integrated between these two density levels are next referred to as $F_{\max }$ and $F_{S \text {,max }}$. Both variables show great variations along the equatorial section, with two local maxima near its two ends and a rapid decrease at the easternmost station (Fig. 9c). These variations probably arise because the along-equatorial section is not exactly the path followed by the EUC, as shown in Figure 5. When the EUC crosses this section (at about stations 38 and 18-19) the transport increases, but it decreases when it moves away.

The fact that our equatorial section is not the precise EUC path is not an insurmountable problem. Our objective is to find out how salinity has diffused vertically, downward-convected from the EUC salinity core through static instabilities. For this purpose we may still use $F$ and $F_{S}$ to calculate an advective salinity value as follows

$$
S_{a d v}=\frac{F_{S}}{F} .
$$

The advective salinity $S_{a d v}$ represents the mean salinity transported between $\sigma_{r}=26.43$ and $\sigma_{\theta}$. We may further define $S_{a d v \text {, max }}$, when the integration goes between $\sigma_{r}=26.43$ and $\sigma_{\max }$, i.e.

$$
S_{a d v, \text { max }}=\frac{F_{S, \text { max }}}{F_{\text {max }}},
$$

as indicative of the mean salinity advected in the vertically-diffusive region below the EUC salinity core.

Figure 10a presents the distribution of $S_{a d v}$ as a function of $\sigma_{\theta}$ along the equatorial section. The maximum $S_{a d v}$ values occur near the sea surface, always less than 36.4. As expected, these values are smaller than $S_{\max }$, which ranges from above 36.8 at the western stations to about 36.4 at the eastern ones (Fig. 6a). The most relevant result is the near-constancy of the salinity advected within the potentially convective region, $S_{a d v, \max }$. It is highest at the western stations (36.3) but decreases beyond station 33, thereafter remaining at near-constant levels of about 36.2, and even increasing with eastward distance (Fig. 6b). 

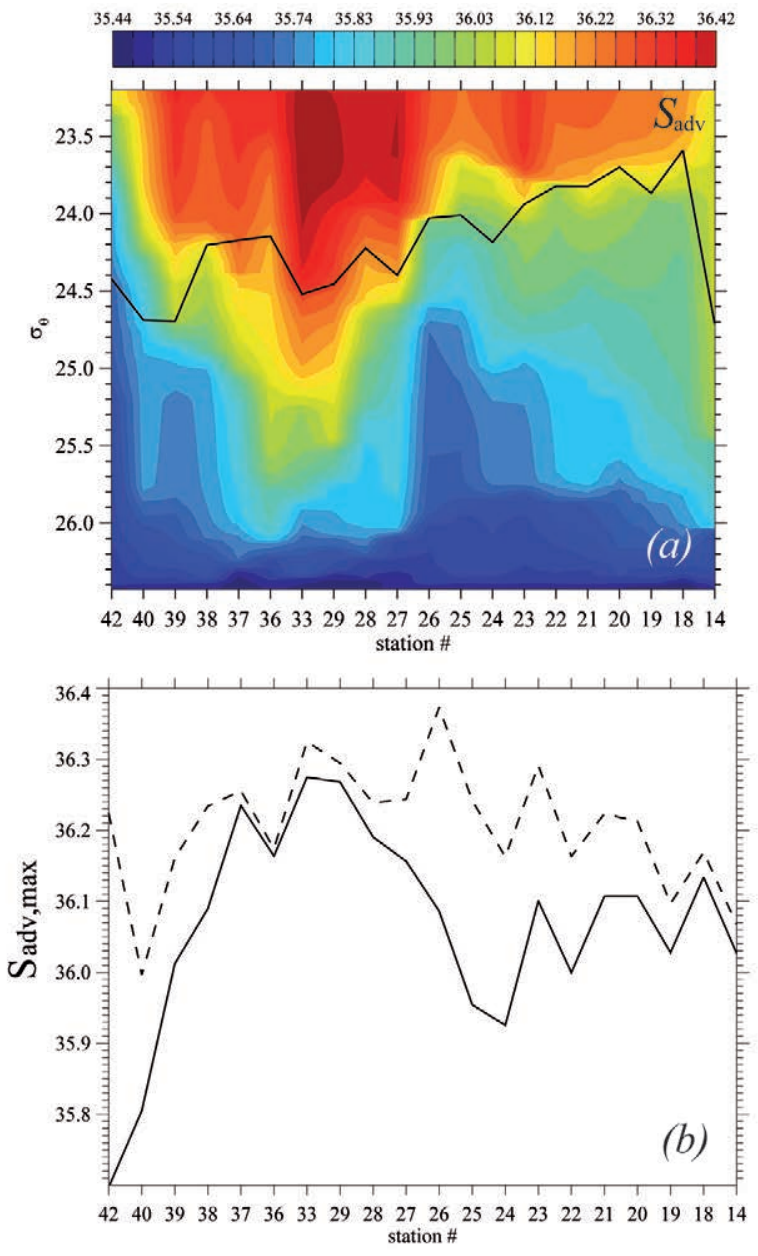

FIG. 10. - (a) Advective salinity $S_{a d v}=F_{S} / F$ plotted as a function of potential density and station number along the equatorial section (from west to east). The solid black line indicates the location of the salinity maximum $S_{\max }$ level at each station. (b) Maximum advective salinity $S_{a d v \max }$, obtained when the water-mass and salt transports are integrated from either $\sigma_{\theta}=26.43$ (solid line) or $\sigma_{\theta}=26.3$ (dashed line) until the salinity-maximum density level, $\sigma_{\max }=\sigma\left(S=S_{\max }\right)$.
The variation of $S_{a d v, \text { max }}$ with longitude is very sensitive to the selection of the $\sigma_{r}$ level. If we were to choose $\sigma_{r}=26.3$, a shallower level where the variance of the salinity anomalies already reaches relatively low values (Fig. 6c), then $S_{a d v, \text { max }}$ would increase eastwards until station 26 but would decrease afterwards (Fig. $10 \mathrm{~b})$. Figure $6 \mathrm{~b}$ indeed shows that at levels between 26.3 and 26.43 the salinity variance is only significant at the central and eastern stations. The vertical extension of the potentially convective region is shown in Figure 4, with the reference level $\sigma_{r}$ deepening between the central and eastern stations. The important message is that $S_{a d v, \text { max }}$ remains high when the whole verticallydiffusive domain is considered (Fig. 10b).

The sustained high values of $S_{a d v, \text { max }}$ are indicative of the existence of convective downwelling from the EUC core. Such water-mass and salt downwelling must have important effects on the circulation patterns in the western tropical Atlantic, specifically on both the tropical and subtropical cells. These cells have been discussed by several authors as being responsible for closing the zonal recirculation currents in the tropical and equatorial Atlantic Ocean (e.g. Molinari et al. 2003, Zhang et al. 2003, Wang 2005). Figure 11 presents a schematic diagram illustrative of this interrelation; this figure is based on schemes in Molinari et al. (2003) and Wang (2005), after taking into account the surface and central water maps by Stramma and Schott (1999) and Zhang et al. (2003). In order to understand the importance of convective mixing within the EUC, we now briefly revise the major characteristics of the tropical and subtropical cells.

The tropical cell is a shallow cell which develops in the surface mixed layer and surface thermocline. It consists of wind-induced upwelling at the equator, poleward wind-induced flow at the surface layer, meridional Ekman transport convergence and downwelling at about $4^{\circ} \mathrm{N}$, and equatorward flow along the surface thermocline into the EUC. Wang (2005) has

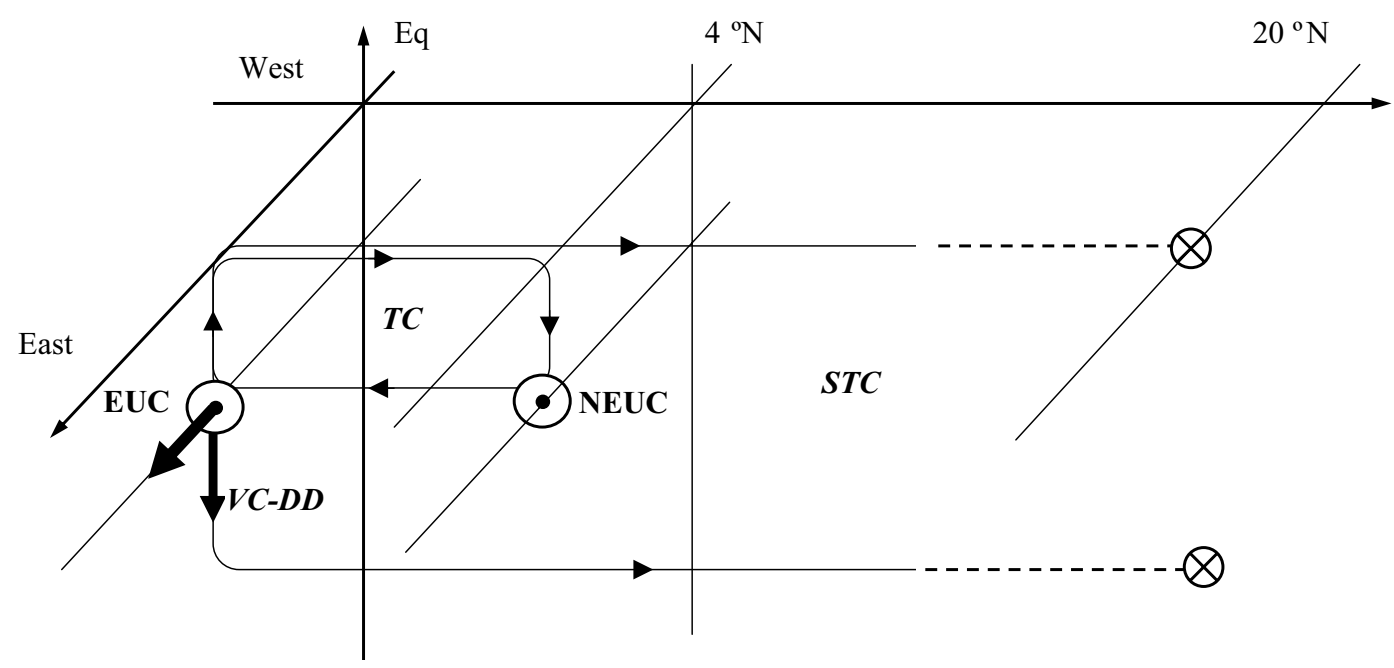

FIG. 11. - Schematic diagram illustrating the connection of the EUC and vertically convective plus double-diffusion downwelling (VC-DD) with the North Atlantic tropical (TC) and subtropical (STC) cells. The EUC and VC-DD arrows are drawn thick to emphasize the importance of the processes studied. 
provided clear evidence that the flow at the surface thermocline is convergent from both hemispheres, therefore being responsible for the maintenance of an intense EUC despite the poleward surface Ekman flow.

The subtropical cell begins at the northern margin of the tropics, in the negative pumping regions located at about $20^{\circ} \mathrm{N}$ to $25^{\circ} \mathrm{N}$ in the North Atlantic, and recirculates along the tropical thermocline into the western boundary. From here the flow returns to the tropical ocean via the eastward zonal jets, namely the EUC and North EUC in the nothern hemisphere. There have been several studies suggesting that the equatorial upper thermocline layers immediately under the EUC are divergent, with poleward flow sustained by a first-mode reversed pressure gradient (from east to west). Further, Wang (2005) has shown that there is equatorial downwelling under the EUC capable of closing the subtropical cell.

Our results confirm the existence of downwelling below the EUC core, and we have shown that one process responsible for this vertical transfer is statically unstable convective mixing. In particular, we have seen that convective downwelling leads to the maintenance of high subsurface salinities before these waters can recirculate north. These high-salinity waters lie between about 150 and $300 \mathrm{~m}$ depth, located on top of much fresher AAIW and therefore giving rise to the possibility of sustained downward salt transfer through double-diffusive processes. Convective downwelling may therefore be an effective mechanism for supplying water mass to the subsurface divergent region and effectively transferring salt to the tropical ocean.

\section{CONCLUDING REMARKS}

The basic dynamics of the EUC follows the ideas presented by Fofonoff and Montgomery (1955) in their description of the Pacific Equatorial undercurrent or Cromwell Current (Cromwell et al. 1954). Conservation of potential vorticity causes water parcels moving towards the equator to gain eastward velocities. The equatorward movement of these parcels is guaranteed by the presence of wind-driven zonal pressure gradients. Therefore, the EUC is a region of horizontal convergence, which increases the initial inflow from the NBC retroflection. Stramma and Schott (1999) showed that the EUC increases its transport from 21.4 Sv at $35^{\circ} \mathrm{W}$ to $36.4 \mathrm{~Sv}$ at $23.5^{\circ} \mathrm{W}$.

Here we have examined how the characteristics of the EUC change from its western end, at about $43^{\circ} \mathrm{W}$, to $32^{\circ} \mathrm{W}$. The most prominent characteristic is the presence of a high-salinity core which intrudes east with the current along the base of the surface thermocline. The salinity anomaly in this core weakens with eastward distance as a result of two possible mechanisms: horizontal convergence of less salty waters and vertical diffusion. Figure 5 shows that input of northern waters, with less salinity, would result in the core dilution. In this study, however, we have focused on the importance of vertical diffusion
Vertical mixing within the EUC has traditionally been attributed to the occurrence of shear-induced mixing. Shear-induced mixing could happen at the upper and lower edges of the EUC core, where vertical shear is large. It should lead to two-way transfer so that the interface would smooth out without significant vertical shifts. However, our observations show that the core rapidly shallows and the salinity structure becomes greatly asymmetrical with respect to the salinity maximum. Therefore, we investigated the likelihood of convective mixing as a result of the intrusion of the high-salinity EUC. This intrusion causes the upper side of the water column to increase its static stability so, in this surface region, only shearinduced and wind-induced mixing can lead to the observed eastward surface salinity increase. However, if salty water penetrates fast enough then the unstable salinity gradient may be large enough for the underlying layers to become statically unstable, leading to mixing and the formation of homogeneous regions, with a step-like structure. To the authors' knowledge there are no previous studies on the existence of vertical convective mixing in the EUC.

We have indeed found numerous instances of wellstratified regions which are statically unstable, considered as locations prone to undergo convective vertical mixing. Such mixing is currently responsible for the effective downwelling of water and salt, clearly visible in the increased fluxes of salt in the layers underlying the EUC. Our results show that intense vertical convection only reaches $\sigma_{\theta}=26.3$ at the western stations and down to $\sigma_{\theta}=26.43$ at the central and eastern stations, no more than the top $150 \mathrm{~m}$. In order for this mixing to penetrate to greater depth, other mechanisms must take over these vertical fluxes. One likely candidate is double-diffusive salt-fingering.

The existence of downwelling has been reported by Wang (2005) and other authors but, until now, no description has been available on how it takes place. This process is likely to be important not only locally but also over the whole tropical Atlantic. The sinking water mass and salt has to drain somewhere in the central or eastern Atlantic as a source term for the upper thermocline recirculation, or subtropical cells.

\section{ACKNOWLEDGEMENTS}

This research has been funded by the Spanish Ministerio de Ciencia e Innovación through projects MOC2 (CTM2008-06438-C02-01), ARGO-CANARIAS (CTM2009-08462-E) and TIC-MOC (CTM201128867) and by the Spanish Ministerio de Educación through two FPU doctoral grants (AP2006-00543 and AP2006-04635). We are grateful to the technicians and crew of R/V Hespérides for their field support and to our cruise colleagues, particularly Ángel Rodríguez Santana and Mikhail Emelianov, for many fruitful discussions. Special thanks are due to José Antonio Pozo, the chief technician during the cruise. 


\section{REFERENCES}

Cromwell T., Montgomery R.B., Stroup E.D. 1954. Equatorial undercurrent in Pacific Ocean revealed by new methods. Science 119: 648-649.

Flagg C.N., Gordon R.L., McDowell S. 1986. Hydrographic and current observations on the continental slope and shelf of the western equatorial Atlantic. J. Phys. Oceanogr. 16: 1412-1429.

Fofonoff N.P., Montgomery R.B. 1955. The Equatorial Undercurrent in the light of the vorticity equation. Tellus 7: 518-521.

Gouriou Y., Reverdin G. 1992. Isopycnal and diapycnal circulation of the upper equatorial ocean in 1983-1984. J. Geophys. Res. 97: 3543-3572

Hebert D., Moum J.N., Caldwell D.R. 1991. Does ocean turbulence peak at the equator?: Revisited. J. Phys. Oceanogr. 21: 1690-1698.

Hüttle-Kabus S., Böning C.W. 2008. Pathways and variability of the off-equatorial undercurrents in the Atlantic Ocean. J. Geophys. Res. 113: C10018.

Jackson L., Hallberg E., Legg S. 2008. A parametrization of sheardriven turbulence for ocean climate models. J. Phys. Oceanogr. 38: 1033-1053.

Metcalf W.G., Voorhis A.D., Stalcup M.C. 1962. The Atlantic Equatorial Undercurrent. J. Geophys. Res. 67: 2499-2508.

Metcalf W.G., Stalcup M.C. 1967. Origin of the Atlantic Equatorial Undercurrent. J. Geophys. Res. 72: 4959-4975.

Molinari R.L., Bauer S., Snowden D., Johnson G.C., Bourles B., Gouriou Y., Mercier H. 2003. A comparison of kinematic evidence for tropical cells in the Atlantic and Pacific Oceans. In Interhemispheric Water Exchange in the Atlantic Ocean. Elsevier Oceanogr. Ser. 68: 269-286.

Neumann G. 1960. Evidence for an equatorial undercurrent in the Atlantic Ocean. Deep-Sea Res. 6: 328-334.

Pacanowsky R.C., Philander S.G.H. 1981. Parametrization of vertical mixing in numerical models of tropical oceans. J. Phys. Oceanogr. 11: 1443-1451.

Peters H., Gregg M.C., Toole J.M. 1988. On the parametrization of equatorial turbulence. J. Geophys. Res. 93: 1199-1218.
Peters H., Gregg M.C., Sanford T.B. 1995. Detail and scaling of turbulent overturns in the Pacific Equatorial Undercurrent. $J$. Geophys. Res. 100: 18349-18368.

Philander S.G.H, Pacanowsky R.C. 1986. A model of the seasonal cycle in the tropical Atlantic Ocean. J. Geophys. Res. 91:14192-14206.

Schott F.A., Fischer J., Stramma L. 1998. Transports and pathways of the upper-layer circulation in the western tropical Atlantic. $J$. Phys. Oceanogr. 28: 1904-1928.

Silva A.C., Bourles B., Araujo M. 2009. Circulation of the thermocline salinity maximum waters off the Northern Brazil as inferred from in situ measurements and numerical results. Ann. Geophys. 27: 1861-1873.

Stramma L., Schott F. 1999. The mean flow field of the tropical Atlantic Ocean. Deep-Sea Res. II 46: 279-303.

Stramma L., Rhein M., Brandt P., Dengler M., Böning C., Walter M. 2005. Upper ocean circulation in the western tropical Atlantic in boreal fall 2000. Deep-Sea Res. I 52: 221-240.

Voorhis A.D. 1961. Evidence of an eastward equatorial undercurrent in the Atlantic from measurements of current shear. Nature 191: 157-158.

Wang C. 2005. Subthermocline tropical cells and equatorial subsurface currents. Deep-Sea Res. I 52: 123-135.

Wang D., Müller P. 2002. Effects of equatorial undercurrent shear on upper-ocean mixing and internal waves. J. Phys. Oceanogr. 32: 1041-1057.

Wyrtki K., Kilonsky B. 1984. Mean water and current structure during the Hawaii-to-Tahiti shuttle experiment. J. Phys. Oceanogr. 14: 242-254.

Zaron E.D., Moum J.N. 2009. A new look at Richardson number mixing schemes for equatorial ocean modeling. J. Phys. Oceanogr. 39: 2652-2664.

Zhang D., McPhaden M.J., Johns W.E. 2003. Observational evidence for flow between the subtropical and tropical Atlantic: The Atlantic subtropical cells. J. Phys. Oceanogr. 33: 1783-1797.

Received March 30, 2011. Accepted July 11, 2011.

Published online August 5, 2012. 